\title{
Identification and optimization of triphenylmethane dyes removal by Streptomyces sp. from forest soil
}

\author{
Nurul Hidayah Adenan ${ }^{1,2}$, Yau Yan Lim ${ }^{1}$ and Adeline Su Yien Ting ${ }^{1 *}$ (D)
}

\begin{abstract}
This study identified a common Streptomyces sp. (MN262194) from forest soil as an efficient decolorizer of triphenylmethane (TPM) dyes. Partial 16S rRNA sequencing identified the isolate as possibly Streptomyces bacillaris (similarity 99.32\%). Live and dead cells of Streptomyces sp. were applied to decolorize Malachite Green (MG), Methyl Violet (MV), Crystal Violet (CV), and Cotton Blue (CB). The decolorization efficacy for both cell types was further optimized based on One-Factor-At-A-Time (OFAT) method to determine the influence of pH, agitation speed (rpm), biomass (g), initial dye concentration ( $\mathrm{mg} \mathrm{L}^{-1}$ ), and oxygen. Removal of TPM dyes was repeated for both live and dead cells using combined optimal conditions determined for each biomass type. Results revealed that optimum conditions for live cells were $\mathrm{pH} \mathrm{7,100} \mathrm{rpm} \mathrm{agitation,} 0.5 \mathrm{~g}$ cell biomass, initial dye concentration of $100 \mathrm{mg} \mathrm{L}^{-1}$ (50 $\mathrm{mg} \mathrm{L}^{-1}$ for $\mathrm{CB}$ ), and with the presence of oxygen. In contrast, $\mathrm{pH} 9$ (MG, MV, CV) and pH 3 (CB), with $100 \mathrm{rpm}$ agitation, $0.75 \mathrm{~g}$ cell biomass, and initial dye concentrations of $100 \mathrm{mg} \mathrm{L}^{-1}\left(50 \mathrm{mg} \mathrm{L}^{-1}\right.$ for CB), were the optimum conditions for dead cells. At optimal conditions, live cells showed significantly higher decolorization activities for all dyes (MG 95\%, MV 92\%, CV 87\%, CB 68\%). Removal of TPM dyes was via biosorption and biodegradation, detected with changes of ultraviolet-visible spectra between the untreated dye and treated dye. Sorption by Streptomyces sp. conforms to the Langmuir isotherm model. Streptomyces sp. was established as an effective decolorizer for most TPM dyes with $>85 \%$ decolorization (with the exception for CB).
\end{abstract}

Keywords: Biodegradation, Bioremediation, Biosorption, Streptomyces sp., Triphenylmethane dyes

\section{Introduction}

Triphenylmethane (TPM) dyes are categorized as one of the larger groups of synthetic dyes after azo dyes [1]. They have three phenyl groups attached to a central carbon atom [1]. TPM dyes are used primarily in the following industries; textile, paper, leather, food, cosmetics, and the aquaculture industry [1]. The discharge of industrial dyes (levels exceeding $0.2 \mathrm{mg} \mathrm{L}^{-1}$ ) pollutes the environment [2]. Dye pollution is rampant as approximately $20 \%$ of unused dye from the industries are

\footnotetext{
* Correspondence: adeline.ting@monash.edu

${ }^{1}$ School of Science, Monash University Malaysia, 47500 Bandar Sunway, Selangor Darul Ehsan, Malaysia

Full list of author information is available at the end of the article
}

released into the environment without proper treatment [3]. According to Abbas et al. [4], dyes have high toxicity and their presence in the environment reduces water quality, and disrupts the water ecosystem [5]. Exposure of living organisms to untreated dyes results in health hazards as dyes are carcinogenic and mutagenic [6]. Any contact, ingestion, or inhalation of these dyes leads to severe complications such as nausea, hemorrhage, skin ulcer, kidney failure, and damage to the central nervous system in humans [5]. Subsequently, several countries, including the United States and European Union restricted the use of TPM dyes, i.e., malachite green (MG) in aquatic products for the treatment of infectious diseases in fish [7].

(c) The Author(s). 2021 Open Access This article is licensed under a Creative Commons Attribution 4.0 International License, which permits use, sharing, adaptation, distribution and reproduction in any medium or format, as long as you give appropriate credit to the original author(s) and the source, provide a link to the Creative Commons licence, and indicate if changes were made. The images or other third party material in this article are included in the article's Creative Commons licence, unless indicated otherwise in a credit line to the material. If material is not included in the article's Creative Commons licence and your intended use is not permitted by statutory regulation or exceeds the permitted use, you will need to obtain permission directly from the copyright holder. To view a copy of this licence, visit http://creativecommons.org/licenses/by/4.0/. 
The removal of dyes from the environment is typically through the employment of physical, chemical, or biological methods. Physical methods involve adsorption and membrane filtration, which have been found to be expensive [8]. On the other hand, chemical techniques like ozonation, photochemical, and the use of Fenton's reagent have been reported to generate toxic sludge [9]. In recent years, biological approaches using microorganisms have received considerable attention [10]. Microbial cells remove dyes via biosorption and/or biodegradation, and these approaches are highly favored as they are ecofriendly, cost-effective, and efficient [11]. The efficacy of dye removal by microbial cells is however, dependent on various factors such as temperature, $\mathrm{pH}$, and dye concentrations [11].

Actinobacteria are Gram-positive bacteria found ubiquitously in the environment [12]. Soil actinobacteria have been documented to be diverse and able to adapt to harsh environmental conditions [12]. Their potential to remove TPM dyes are however not well understood, although in recent years they have been found to remove azo dyes, heavy metals, and pesticides [12]. Streptomyces is the largest genus of actinobacteria with more than 800 species [13]. They are predominantly isolated from environmental samples and are also the most studied genus of actinobacteria. Among the many species of Streptomyces, several have been reported to have the potential to remove dyes. This includes Streptomyces chromofuscus on Acid Yellow 9 via biodegradation [14]; Streptomyces coelicolor on Acid Blue 74, Direct Sky Blue 6b, Reactive Black 5, Reactive Blue 19, and Congo Red via biodegradation [15]; Streptomyces krainskii on Reactive Blue-59 via biodegradation [16]; Streptomyces globosus, Streptomyces alanosinicus, Streptomyces ruber, Streptomyces gancidicus on Acid Fast Red and Congo Red via biosorption [17]; and Streptomyces microflavus on Crystal Violet (CV) and Safranin T (ST) via biodegradation [11]. These common soil species of actinobacteria [18] have also been reported to have roles in the bioremediation of hydrocarbons [19], biosorption of heavy metals [20], and as biocontrol agents [21]. There is, however, a gap in the knowledge on their potential to remove various TPM dyes.

This study aims to discover the potential of Streptomyces sp. in removing TPM dyes and to establish the optimum conditions (i.e., $\mathrm{pH}$, agitation speed (rpm), biomass (g), initial dye concentration $\left(\mathrm{mg} \mathrm{L}^{-1}\right)$, and presence of oxygen) for the decolorization of Malachite Green (MG), Methyl Violet (MV), Crystal Violet (CV) and Cotton Blue (CB). This study has elements of novelty in that the actinobacterial isolate was isolated from a pristine environment rather than a contaminated environment. Actinobacteria are known to inhabit soil naturally, but less so in polluted environments such as effluents. The focus of TPM dyes is also significant as these dyes are rarely studied, hence the documentation on removal of $\mathrm{MG}, \mathrm{CB}, \mathrm{MV}$ and $\mathrm{CV}$, would be highly beneficial.

\section{Materials and methods \\ Preparation of TPM dyes}

The TPM dyes, i.e., MG $\left(\mathrm{C}_{52} \mathrm{H}_{54} \mathrm{~N}_{4} \mathrm{O}_{12}\right.$, basic dye, $60 \mathrm{~g}$ $\mathrm{L}^{-1}$ water solubility at $20{ }^{\circ} \mathrm{C}, 98 \%$ purity) (Riendemann Schmidt, Malaysia), MV $\left(\mathrm{C}_{24} \mathrm{H}_{28} \mathrm{ClN}_{3}\right.$, basic dye, $30 \mathrm{~g}$ $\mathrm{L}^{-1}$ water solubility at $20^{\circ} \mathrm{C}, 98 \%$ purity) (Sigma-Aldrich, Malaysia), $\mathrm{CV}\left(\mathrm{C}_{25} \mathrm{H}_{30} \mathrm{ClN}_{3}\right.$, basic dye, $50 \mathrm{~g} \mathrm{~L}^{-1}$ water solubility at $20^{\circ} \mathrm{C}, 98 \%$ purity) (Merck, Malaysia), and $\mathrm{CB}\left(\mathrm{C}_{37} \mathrm{H}_{27} \mathrm{~N}_{3} \mathrm{Na}_{2} \mathrm{O}_{9} \mathrm{~S}_{3}\right.$, acid dye, $70 \mathrm{gL}^{-1}$ water solubility at $20^{\circ} \mathrm{C}, 99 \%$ purity) (Sigma-Aldrich, Malaysia) were weighed and dissolved in autoclaved MilliQ water (Sartorius, Malaysia) to a concentration of $100 \mathrm{mg} \mathrm{L}^{-1}$ (CB at $50 \mathrm{mg} \mathrm{L}^{-1}$ ) [22].

\section{Isolation and molecular typing of actinobacterial isolate}

Soil samples were collected at random from Kuala Lumpur Eco Forest Park, Malaysia (N3.1499235, E 101.7023324). The isolated colony was obtained using streak plate technique and maintained on Actinomycetes Isolation Agar (Difco, USA), containing Nystatin (Sigma-Aldrich, Malaysia; $\geq 95 \%$ purity) and Nalidixic acid (Sigma-Aldrich, Malaysia; $\geq 98 \%$ purity) to prevent the growth of fungi and non-actinobacteria, respectively. The incubation was carried out for $7 \mathrm{~d}$ $\left(30 \pm 2{ }^{\circ} \mathrm{C}\right)$. For molecular typing, the isolate was first inoculated into $100 \mathrm{~mL}$ of International Streptomyces Project Medium (Difco, USA) and incubated (100 $\mathrm{rpm}, 7 \mathrm{~d})$ at $30 \pm 2{ }^{\circ} \mathrm{C}$. The genomic DNA was extracted (GF-1 Bacterial DNA Extraction Kit, Vivantis Technologies, USA) and amplified (MJ Mini Thermal Cycler, Biorad, USA) using primers specific for actinobacteria; S-C-Act-878-a-A-19 (CCGTACTCCC CAGGCGGGG) and S-C-Act-235-a-S-20 (CGCGGC CTATCAGCTTGTTG). DNA purification was performed using MEGAquick-spin Total Fragment DNA Purification Kit (iNtRON Biotechnology, Korea) and sent for sequencing to Apical Scientific Sequencing (Singapore). The sequences were analyzed using Basic Local Alignment Search Tool (http://blast.ncbi.nlm. nih.gov/). A phylogenetic tree was generated using the Molecular Evolutionary Genetics Analysis (Version 10.0.5) [23].

To generate biomass, the culture was first inoculated into the International Streptomyces Project Medium-1 (ISP-1) (Difco, USA) and incubated $\left(30 \pm 2{ }^{\circ} \mathrm{C}\right)$ for $7 \mathrm{~d}$ at $100 \mathrm{rpm}$. To obtain dead cells, the broth cultures were centrifuged $(7000 \mathrm{rpm}, 20 \mathrm{~min})$, autoclaved $\left(121^{\circ} \mathrm{C}, 20\right.$ min), and filtered through Whatman filter paper No. 1. The live cells were obtained similarly, with the exclusion 
of autoclaving [24]. Both types of biomass (fresh weight) were then weighed to the required weight (e.g., 0.5, 1.0 g) and used for decolorization and optimization studies of TPM dyes.

\section{Dye decolorization studies}

Live cells $(1.0 \pm 0.1 \mathrm{~g})$ were introduced into $100 \mathrm{~mL}$ of $\mathrm{MG}, \mathrm{MV}, \mathrm{CV}$, and $\mathrm{CB}$ dye solutions, and the mixture was incubated $\left(100 \mathrm{rpm}, 30 \pm 2{ }^{\circ} \mathrm{C}\right)$ for $14 \mathrm{~d}$. A separate set was prepared similarly using dead cells. Throughout the incubation period, $3 \mathrm{~mL}$ of aliquot was withdrawn and centrifuged $(10,000 \mathrm{rpm})$ at every $24 \mathrm{~h}$ interval. The supernatant obtained was read using Spark $10 \mathrm{M}$ multimode microplate reader (Tecan, USA) at $\lambda$ max of 617 , 584,590 , and $599 \mathrm{~nm}$ for MG, MV, CV, and CB, respectively. The decolorization efficiency (DE) was calculated according to Eq. (1) [22].

$$
\mathrm{DE}=\frac{\text { initial absorbance }- \text { observed absorbance }}{\text { initial absorbance }} \times 100
$$

\section{Optimization studies for decolorization of TPM dyes by live and dead cells of Streptomyces sp.}

The One-Factor-At-A-Time (OFAT) approach was adopted to optimize the following parameters; $\mathrm{pH}$, agitation speed (rpm), biomass (g), initial dye concentration $\left(\mathrm{mg} \mathrm{L}^{-1}\right)$, and oxygen. Conditions were optimized by modifying the respective parameters from the standard protocol of OFAT, i.e., examining one parameter while keeping the other parameters at a pre-determined level [25]. Both live and dead cells of Streptomyces sp. were tested, with the exception of the influence of oxygen, where only live cells were used.

To determine the optimum $\mathrm{pH}$, the initial $\mathrm{pH}$ of TPM dyes (using concentration $\mathrm{MG}, \mathrm{MV}, \mathrm{CV}$ at $100 \mathrm{mg} \mathrm{L}^{-1}$, while $\mathrm{CB}$ at $50 \mathrm{mg} \mathrm{L}^{-1}$ ) was adjusted to 3, 5, 7, and 9. The optimization test was performed, as defined previously. To determine optimum agitation speed, dye solutions were treated with cell biomass and agitated at 50, 100, $150 \mathrm{rpm}$, while other factors remained constant. To determine the optimum biomass, 0.25, 0.5, 0.75, and 1.0 $\mathrm{g}$ was introduced into the dye solutions while keeping the other factors constant. To determine the optimum initial dye concentration, dye solutions $(50,75,100$, and $125 \mathrm{mg} \mathrm{L}^{-1}$ of MG, MV, and CV; 10, 25, 50, and $75 \mathrm{mg}$ $\mathrm{L}^{-1}$ of $\mathrm{CB}$ ) were tested, and other factors were kept constant. To examine the influence of the absence of oxygen, $100 \mathrm{~mL}$ dye solutions $\left(100 \mathrm{mg} \mathrm{L}^{-1}\right.$ of MG, MV, CV, and $50 \mathrm{mg} \mathrm{L}^{-1}$ of $\mathrm{CB}$ ) were inoculated with $1.0 \pm 0.1 \mathrm{~g}$ of cell biomass and overlaid with $2 \mathrm{~mL}$ of paraffin oil. The mixture was incubated as a standing culture. A separate set of flasks was prepared similarly, with the exclusion of paraffin overlay, to determine the decolorization of TPM dyes with the presence of oxygen.

Removal of TPM dyes by Streptomyces sp. (live and dead cells) using optimized conditions

The optimized conditions from the OFAT test for live cells were combined and used to decolorize all TPM dyes, as described in previuos section. The dye supernatant was sampled at 2, 4, 6, 8, and $24 \mathrm{~h}$. The DE was determined using Eq. (1) [22]. This was repeated for MG, MV, CV, and CB using dead cells under the same experimental conditions.

\section{Adsorption isotherm models}

Two common isotherm models, i.e., Langmuir and Freundlich, were employed to determine the relationship between the biosorption of live cells with TPM dyes at an equilibrium state [26].

The Langmuir isotherm equation is shown in Eq. (2):

$$
\frac{C_{e}}{q_{e}}=\left(\frac{1}{K_{L} q_{m}}\right)+\left(\frac{1}{q_{m}}\right) C_{e}
$$

where $q_{e}, C_{e}, K_{L}$, and $q_{m}$ indicate the quantity of dye absorbed ( $\mathrm{mg} \mathrm{g}^{-1}$ ), equilibrium dye concentration (mg $\left.\mathrm{L}^{-1}\right)$, Langmuir constant $\left(\mathrm{L} \mathrm{mg}^{-1}\right)$, and biosorption capacity $\left(\mathrm{mg} \mathrm{g}^{-1}\right)$, respectively. $K_{L}$ and $q_{m}$ were calculated from the intercept and slope of the linear plot of $C_{e} / q_{e}$ against $C_{e}$. The characteristics of Langmuir isotherm is expressed by a separation factor, $R_{L}$, as written in Eq. (3):

$$
R_{L}=\frac{1}{\left(1+K_{L} C_{o}\right)}
$$

where $C_{O}$ is the initial dye concentration $\left(\mathrm{mg} \mathrm{L}^{-1}\right)$.

The Freundlich isotherm is given in Eq. (4):

$$
\ln q_{e}=\ln K_{F}+\left(\frac{1}{n}\right) \operatorname{In} C_{e}
$$

where $K_{f}$, and $n$ refer to biosorption capacity $\left(\mathrm{mg} \mathrm{g}^{-1}\right)$, and biosorption intensity, respectively. $K_{f}$, and $n$ were determined from the intercept and slope of the linear plot of $\ln q_{e}$ against $\ln C_{e}$.

\section{Ultraviolet-visible (UV-vis) analysis for TPM dyes treated using optimized conditions}

UV-vis analysis was performed to determine the underlying mechanisms for the removal of TPM dyes by Streptomyces sp., conducted at optimized conditions. The dye solutions were examined by comparing the changes in the spectra between the untreated and treated dye. The untreated dye (non-inoculated with biomass) $(0 \mathrm{~h})$ and the treated dye $(24 \mathrm{~h})$ were collected and centrifuged $(10,000 \mathrm{rpm}, 10 \mathrm{~min})$. The supernatant was 
collected and absorption spectra were scanned at wavelengths of 200 to $800 \mathrm{~nm}$ using a LAMBDA $365 \mathrm{UV}$-Vis spectrophotometer (Perkin Elmer, USA) [24].

\section{Statistical analysis}

All decolorization assays were conducted in triplicates, and untreated dyes (non-inoculated dye) was designed as a negative control. The data were analyzed using One-Way Analysis of Variance with statistical analysis performed with the Statistical Package for Social Sciences (Version 24.0). Means were compared using the Tukey-Kramer multiple comparison test (honestly significant difference (HSD), $P<0.05)$ or paired $T$-test $(P<0.05)$, when applicable.

\section{Results and discussion}

\section{Identification of actinobacterial isolate}

The isolated colony appeared powdery, yellowish-gray in color, and produced an earthy odor. The observed morphologies were aligned with species of Streptomyces described in other studies, where they appeared powdery [27], and colonies were of various pigmentation, e.g., white, gray, and yellow [27]. Streptomyces spp. were also reported to produce a distinct earthy odor, derived from a compound known as geosmin [28]. Results from 16S rRNA partial sequencing with primer pairs of S-C-Act-878-a-A-19 (CCGTACTCCC CAGGCGGGG) and S-C-Act-235-a-S-20 (CGCGGC CTATCAGCTTGTTG) suggested that the isolate is presumably Streptomyces bacillaris (query cover 99\%, similarity 99.32\%). The query cover and similarity were however, not $100 \%$ suggesting the possibility in species variation, which can be further determined using whole-genome sequencing. In fact, the phylogenetic analysis revealed that S. bacillaris is closely related to other Streptomyces spp. such as Streptomyces sp. (MH807549), Streptomyces sp. (MH807556), S. luridiscabiei (MN262203), S. cavourensis (MN865771), and Streptomyces sp. (MH807557) (Fig. 1). Nevertheless, the analyzed partial sequence for the Streptomyces sp. was deposited in the GenBank, and the accession number MN262194 was assigned to $S$. bacillaris. This isolate (S. bacillaris.) is clustered with other Streptomyces isolates commonly found in soil environment (Fig. 1).

\section{Decolorization of TPM dyes by Streptomyces sp.}

The Streptomyces isolate showed strong potential in decolorizing TPM dyes. The DE exhibited by live cells was significantly higher compared to dead cells (Fig. 2). Live cells decolorized 95, 95, 91, and 64\% of MG, MV, CV, and $\mathrm{CB}$, respectively (Fig. 2). Dead cells, on the other

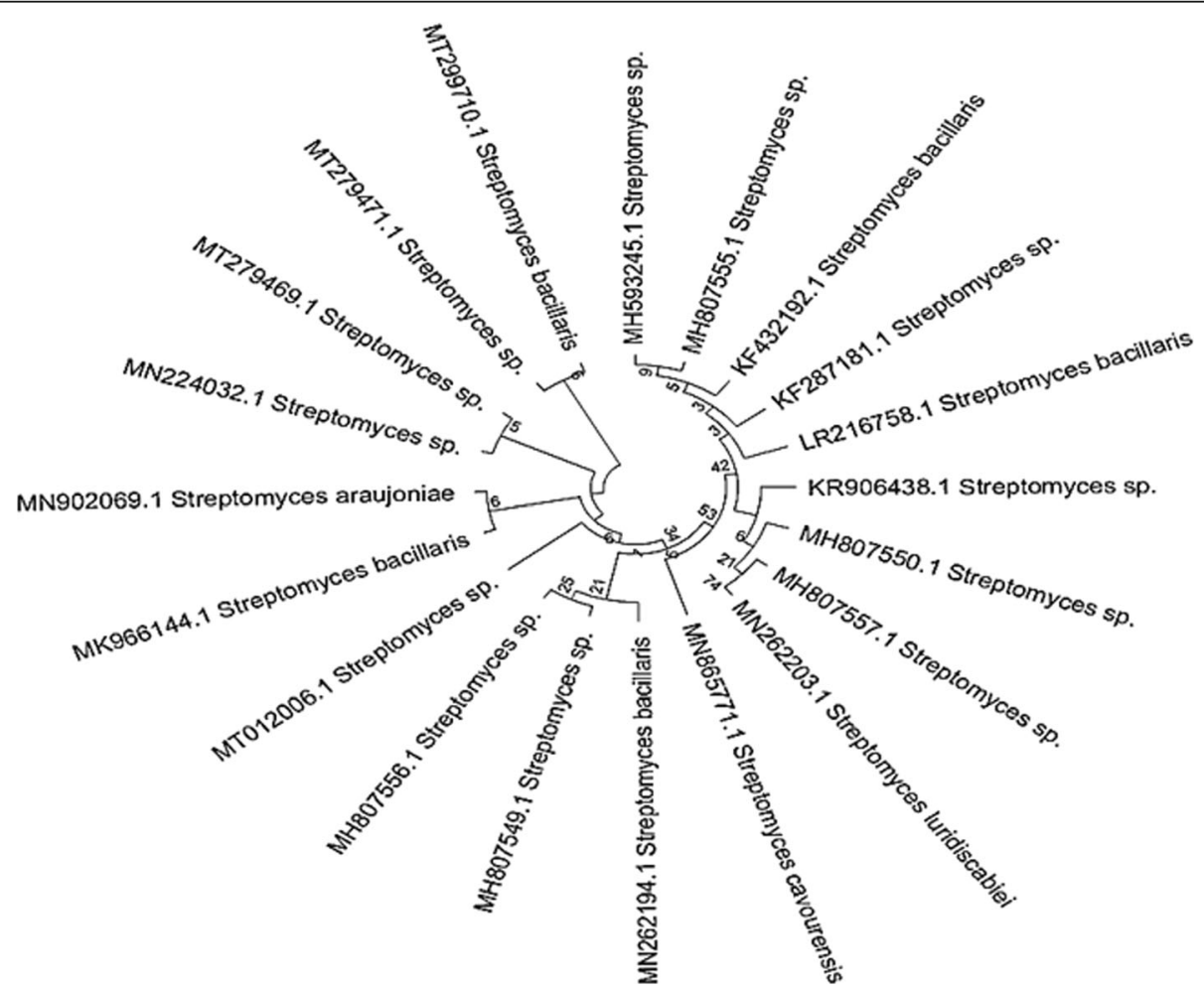

Fig. 1 Phylogram (phylogenetic tree) showing relationships of presumed Streptomyces bacillaris MN262194 based on partial sequencing of the 165 nucleotide sequences with other Streptomyces species 


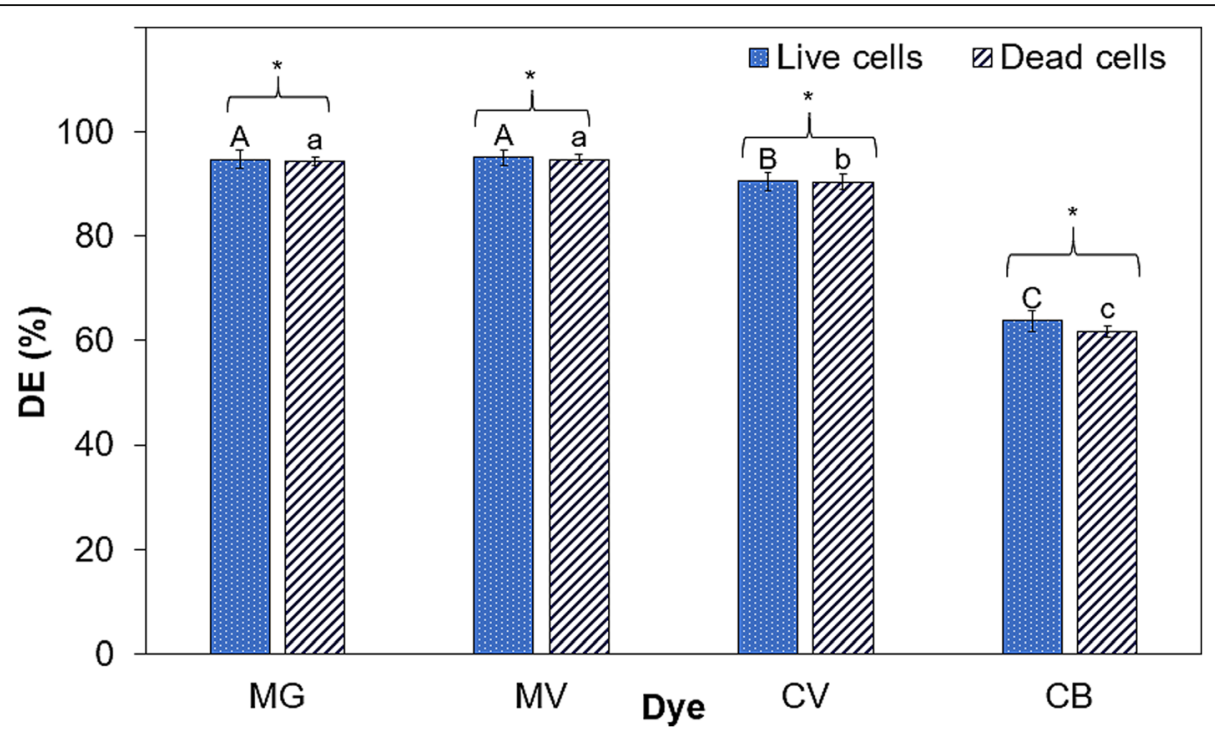

Fig. 2 Comparison of maximum DE by live and dead cells on TPM dyes using non-optimized conditions (biomass dosage $1.0 \mathrm{~g}$, agitation 100 rpm, $\mathrm{pH} 5$, incubation at $30^{\circ} \mathrm{C}$ ). Means with the same capital letters (live cells) and the same small letters (dead cells) are not significantly different at HSD (0.05). Bars indicate standard error of mean $\left( \pm\right.$ SEM). ${ }^{\prime * \prime}$ indicates significant difference based on paired $T$-test $(p<0.05)$ between live and dead cells

hand, demonstrated a slightly lower efficiency for the removal of MG (94\%), MV (95\%), CV (91\%), and CB (62\%) (Fig. 2). The most rapid decolorization was performed by dead cells, where 93\% (MG), 92\% (MV), 89\% (CV), and $37 \%(\mathrm{CB})$ were removed within $4 \mathrm{~d}$ (Fig. 3). This rate of decolorization contrasted with the rate of decolorization by live cells, which were more gradual and took $8 \mathrm{~d}$ to achieve $929,41,91$, and $56 \%$ of DE for MG, MV, CV, and CB, respectively (Fig. 3). This study has shown that live cells of Streptomyces sp. require a

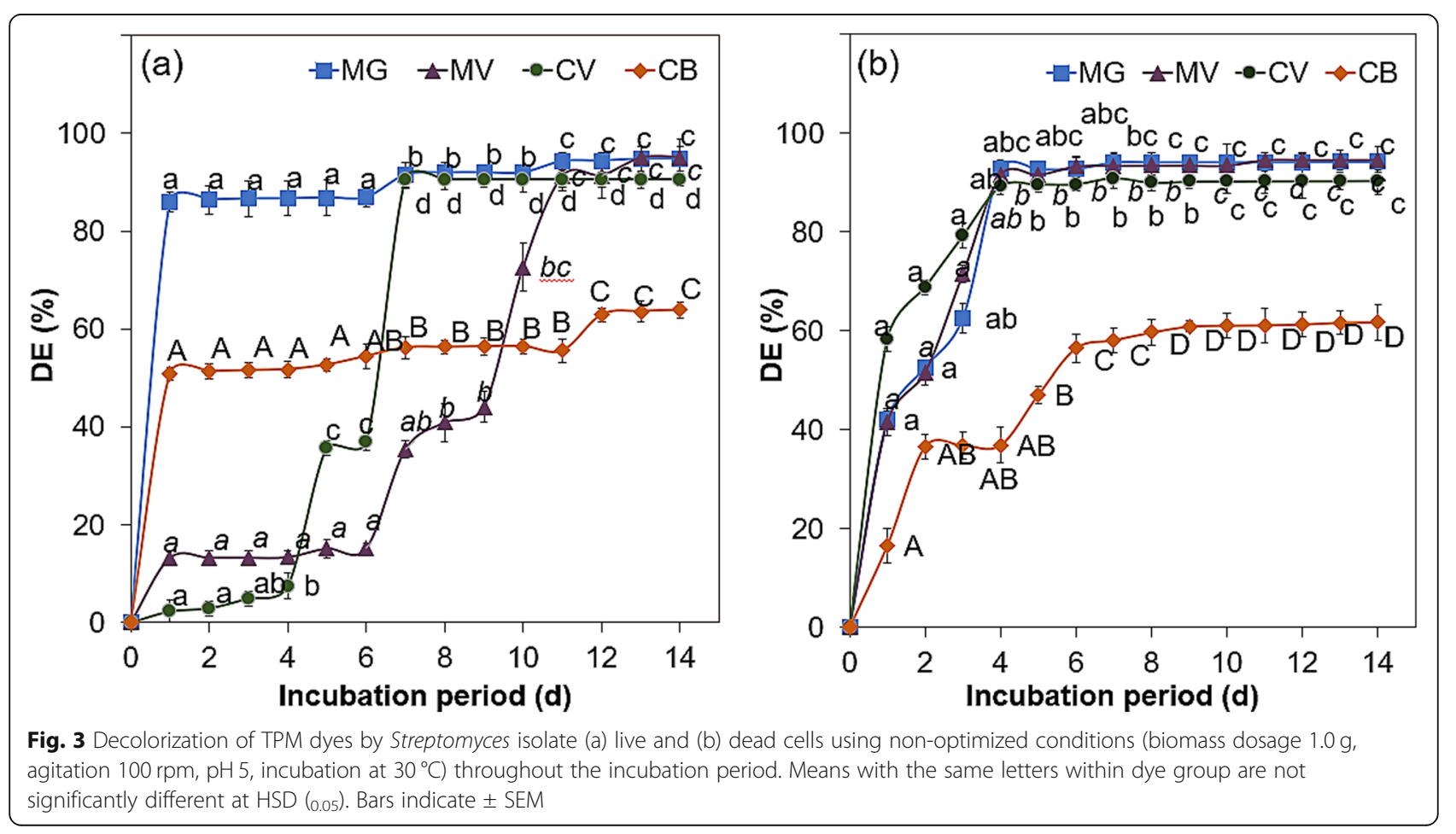


longer incubation period despite their superiority in decolorizing TPM dyes. This may be attributed to the lag phase of cell growth, the adaptation to the presence of toxic dyes, and the period required for enzyme biodegradation [22, 24]. The rapid decolorization by dead cells compared to live cells was also demonstrated by Diaporthe sp., a fungal endophyte. Dead cells removed TPM dyes (MG, MV, $\mathrm{CV}, \mathrm{CB}$ ) within $3 \mathrm{~h}$, whereas live cells decolorized the dye effectively by 24-120 h [24]. Streptomyces sp., notably in the form of live cells, has the potential for effective removal of TPM dyes.

\section{Effect of different $\mathrm{pH}$ on decolorization of TPM dyes by live and dead cells}

Decolorization of TPM dyes by live and dead cells of Streptomyces sp. was influenced by the changes in $\mathrm{pH}$. For live cells, decolorization was optimum at $\mathrm{pH}$ 7 for all TPM dyes tested; MG (96\%), MV (95\%), CV (94\%), and CB (66\%) (Fig. 4). The decolorization at a lower or higher $\mathrm{pH}$ however, was less efficient than the efficacy achieved at $\mathrm{pH} 7$. The $\mathrm{DE}$ was significantly lower at a lower $\mathrm{pH}$, with $14-66 \%$ and $48-89 \%$ at $\mathrm{pH} 3$ and 5, respectively (Fig. 4). At a higher $\mathrm{pH}$, decolorization of TPM dyes varied, i.e., 63-96\% of DE at $\mathrm{pH} 9$ (Fig. 4). The optimum $\mathrm{pH}$ ( $\mathrm{pH} 7$ ) observed in this study was also the optimum $\mathrm{pH}$ for the removal of azo blue dye and CV by live cells of Streptomyces DJP15 [29] and S. microflavus CKS6 [11], respectively. This may be due to the fact that Streptomyces species prefer neutral $\mathrm{pH}$ for their growth and enzyme production [30], which perhaps leads to more efficient degradation of dyes at near-neutral $\mathrm{pH}$ [29]. The poor removal of TPM dyes in $\mathrm{pH} 3$ and 5 may be attributed to their poor tolerance to grow in acidic $\mathrm{pH}$ [31]. According to Kontro et al. [30], the proliferation of Streptomyces occurs optimally within a $\mathrm{pH}$ range from neutral to slightly alkaline. Nevertheless, $\mathrm{pH} 7$ was documented as an optimum $\mathrm{pH}$ for their growth [29], as obtained in this study.

In contrast, the optimum $\mathrm{pH}$ for dead cells varied depending on the TPM dye. Removal of MG (95\%), MV (95\%), and CV (91\%) was more efficient at a higher $\mathrm{pH}(\mathrm{pH} 9)$, while optimum $\mathrm{pH}$ for removal of $\mathrm{CB}(69 \%)$ was at lower $\mathrm{pH}(\mathrm{pH} 3)$ (Fig. 4). The DE of cationic TPM dyes (MG, MV, and CV) increased with $\mathrm{pH}$ due to the negatively charged surface of Streptomyces sp. [32]. As a result, the electrostatic interaction of dye molecules with functional groups on the biomass surface is enhanced [32]. CB however, is a type of anionic dye [33]. The negatively charged $\mathrm{CB}$ binds well to the biomass at low $\mathrm{pH}$; as biomass surface is positively charged at lower $\mathrm{pH}$, resulting in increased electrostatic forces with the negatively charged anionic dye [32]. This study showed that ionic activity between dead cells and dye ions has a profound effect on the decolorization of TPM dyes.

\section{Effect of agitation speed on decolorization of TPM dyes by live and dead cells}

The decolorization of TPM dyes was affected by agitation speed. For both types of cell biomass, the optimum agitation speed was $100 \mathrm{rpm}$. With $100 \mathrm{rpm}$, live and dead cells decolorized MG, MV, CV and CB at 97, 95, 92, 64\% and 96, 95, 91, and 68\%, respectively (Fig. 5). On the contrary, agitation at 50 and $150 \mathrm{rpm}$ was less

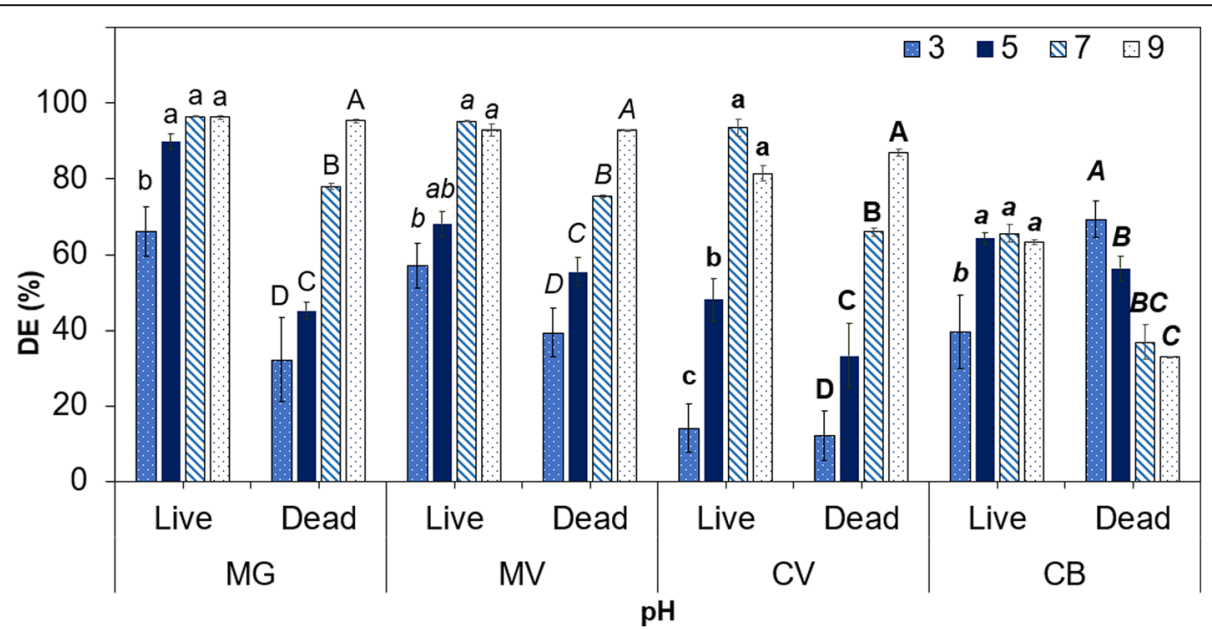

Fig. 4 Effect of pH on the DE of TPM dyes by Streptomyces isolate (live and dead cells). Means with the same letters (lowercase, live cells; uppercase, dead cells) and font style (MG, regular; $\mathrm{MV}$, italic; $\mathrm{CV}$, bold; $\mathrm{CB}$, bold italic) are not significantly different at HSD (0.05). Bars indicate \pm SEM 


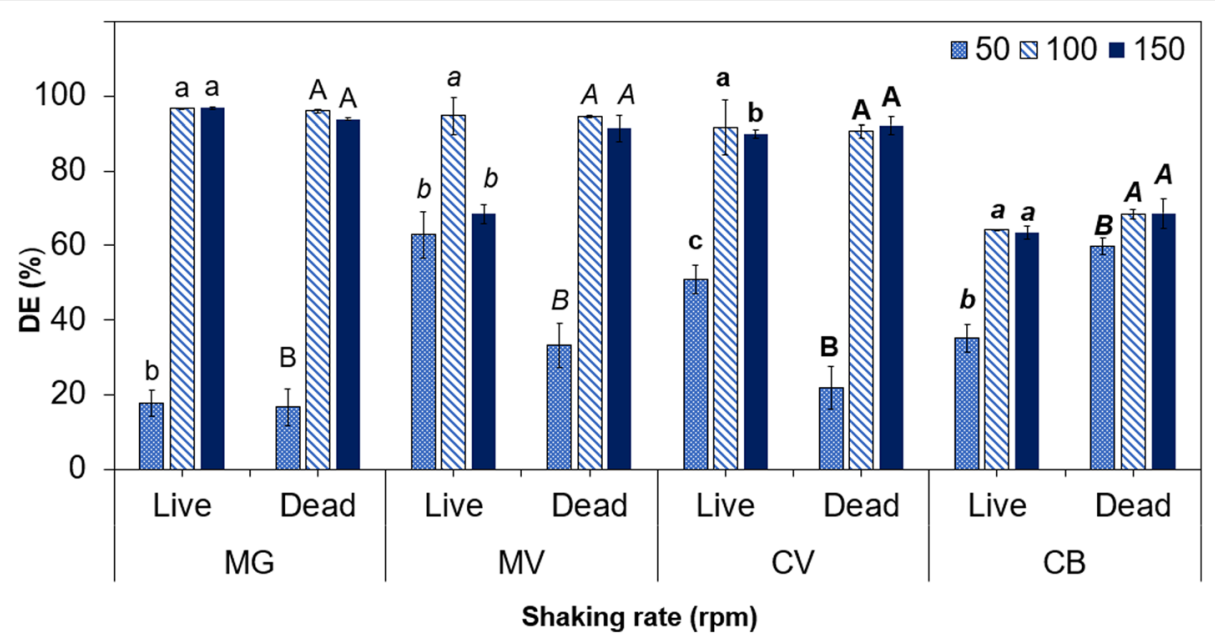

Fig. 5 Effect of agitation speed on the DE of TPM dyes by Streptomyces isolate (live and dead cells). Means with the same letters (lowercase, live cells; uppercase, dead cells) and font style (MG, regular; MV, italic; CV, bold; CB, bold italic) are not significantly different at HSD (o.05). Bars indicate \pm SEM

effective than at $100 \mathrm{rpm}$, for all dyes treated with live and dead cells. At $50 \mathrm{rpm}$, the DE of TPM dyes was significantly lower, with $17-62 \%$ and $21-59 \%$ by live and dead cells, respectively (Fig. 5). At $150 \mathrm{rpm}$, there was no substantial difference observed for the removal of TPM dyes, i.e., $63-96 \%$ and $68-93 \%$ by live and dead cells, respectively (Fig. 5). It is postulated that the significant increase in DE at $100 \mathrm{rpm}$ by live cells is associated with increased distribution of nutrients and oxygen transfer as a consequence of agitation [34]. Agitation at $100 \mathrm{rpm}$ also enhanced decolorization by dead cells as there is better surface contact and distribution with dye molecules for biosorption [32].
At lower agitation speed (e.g., $50 \mathrm{rpm}$ ), the growth of live cells of Streptomyces may have been suppressed due to aeration and nutrient deficiency [34]. Lower agitation speed may also cause accumulation of particles [32], resulting in uneven dispersion of dead cells and dye molecules. By contrast, a higher agitation speed (150 rpm) results in constant contact of particulate with the surface of live cells [34] and biosorption rate of dyes [32], which is not significantly different from results derived from agitation speed of $100 \mathrm{rpm}$. As such, it is postulated that agitation with $150 \mathrm{rpm}$ is similar to $100 \mathrm{rpm}$, primarily attributed to the availability of sorption sites. This study has revealed that $100 \mathrm{rpm}$ agitation was sufficient for live

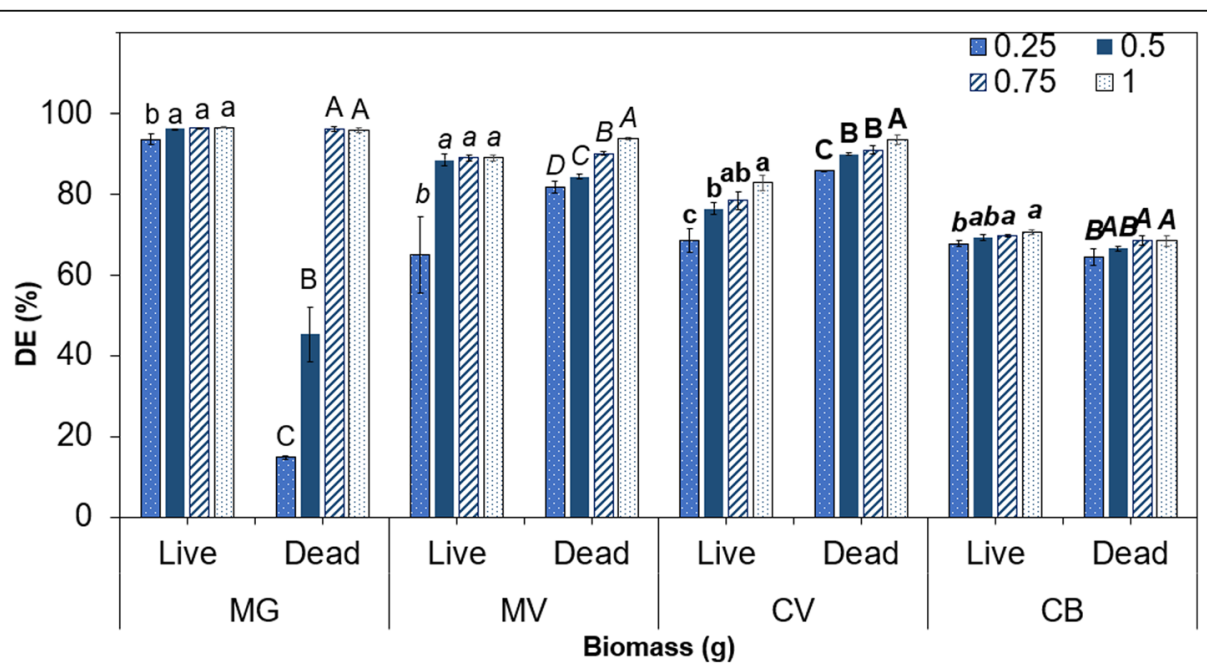

Fig. 6 Effect of biomass concentration of Streptomyces isolate (live and dead cells) on the DE of TPM dyes. Means with the same letters (lowercase, live cells; uppercase, dead cells) and font style (MG, regular; MV, italic; CV, bold; CB, bold italic) are not significantly different at HSD (o.05). Bars indicate \pm SEM 
and dead cells of Streptomyces to attain efficient removal of TPM dyes.

\section{Effect of biomass on decolorization of TPM dyes by live and dead cells}

Findings indicated that the optimum biomass for efficient removal of TPM dyes differed, depending on whether live or dead cells were used. For live cells, the minimum biomass required was $0.5 \mathrm{~g}$, with a significant increase in DE of all TPM dyes, compared to the use of $0.25 \mathrm{~g}$. With $0.5 \mathrm{~g}$ of cell biomass, the maximum DE achieved was generally high for MG (96\%), MV (89\%), CV (77\%), and CB (69\%) (Fig. 6). With the use of a higher amount of biomass (i.e., 0.75 and $1.0 \mathrm{~g}$ ), a slight increase in DE was observed (Fig. 6). On the contrary, dead cells showed $0.75 \mathrm{~g}$ as the minimum biomass required for efficient decolorization of MG (96\%), MV (90\%), CV (91\%), and CB (69\%) (Fig. 6). When the amount of biomass was increased to $1.0 \mathrm{~g}$, decolorization efficiency was improved for only two dyes; MV and CV, with $94 \%$ for each dye (Fig. 6). This test indicated that 0.5$0.75 \mathrm{~g}$ might be the optimum amount of biomass for the efficient removal of TPM dyes by the Streptomyces isolate. The use of less than $1.0 \mathrm{~g}$ of bacterial biomass was also documented in previous studies for the decolorization of azo dyes [35, 36]. Higher DE for all TPM dyes was observed when greater amounts of biomass were used. This may be attributed to higher secretion of enzymes by live cells [37] and greater sorption of dye molecules onto the dead cells surface [32]. This is definitely superior to the use of lesser biomass as lesser biomass indicated lower DE, presumably due to the lower enzyme activity [37] and lesser availability of binding sites for dye molecules [35]. However, biomass exceeding 1.0 $\mathrm{g}$ is not considered for application as their production requires additional costs [32].

\section{Effect of dye concentrations on decolorization of TPM dyes by live and dead cells}

Results indicated that initial dye concentrations influenced the decolorization of TPM dyes. The optimum concentrations for the removal of TPM dyes by live and dead cells were $100 \mathrm{mg} \mathrm{L}^{-1}$ for MG, MV, CV, and 50 $\mathrm{mg} \mathrm{L}^{-1}$ for CB. Decolorization achieved by live and dead cells at lower dye concentrations (i.e., 50 and $75 \mathrm{mg} \mathrm{L}^{-1}$ for MG, MV, CV; 10 and $25 \mathrm{mg} \mathrm{L}^{-1}$ for $\mathrm{CB}$ ) did not differ significantly from DE at optimal dye concentrations, while removal at higher dye concentrations decreased considerably (i.e., $125 \mathrm{mg} \mathrm{L}^{-1}$ for MG, MV, CV; $75 \mathrm{mg}$ $\mathrm{L}^{-1}$ for $\mathrm{CB}$ ). It is evident that Streptomyces was capable of tolerating high concentrations of TPM dyes, which may be advantageous for the treatment of wastewaters from textile industries (with 10 to $50 \mathrm{mg} \mathrm{L}^{-1}$ dye concentrations) [38]. For live cells, decolorization efficacies of $97,89,88$, and $66 \%$ were achieved for MG, MV, CV, and $\mathrm{CB}$, respectively (Fig. 7). Higher dye concentrations resulted in a reduction in $\mathrm{DE}$, while lower dye concentrations led to an increase in DE (Fig. 7). Higher dye concentrations may inadvertently impose toxicity to live cells, implicating viability of cells and their enzyme activities, and subsequently the DE [37].

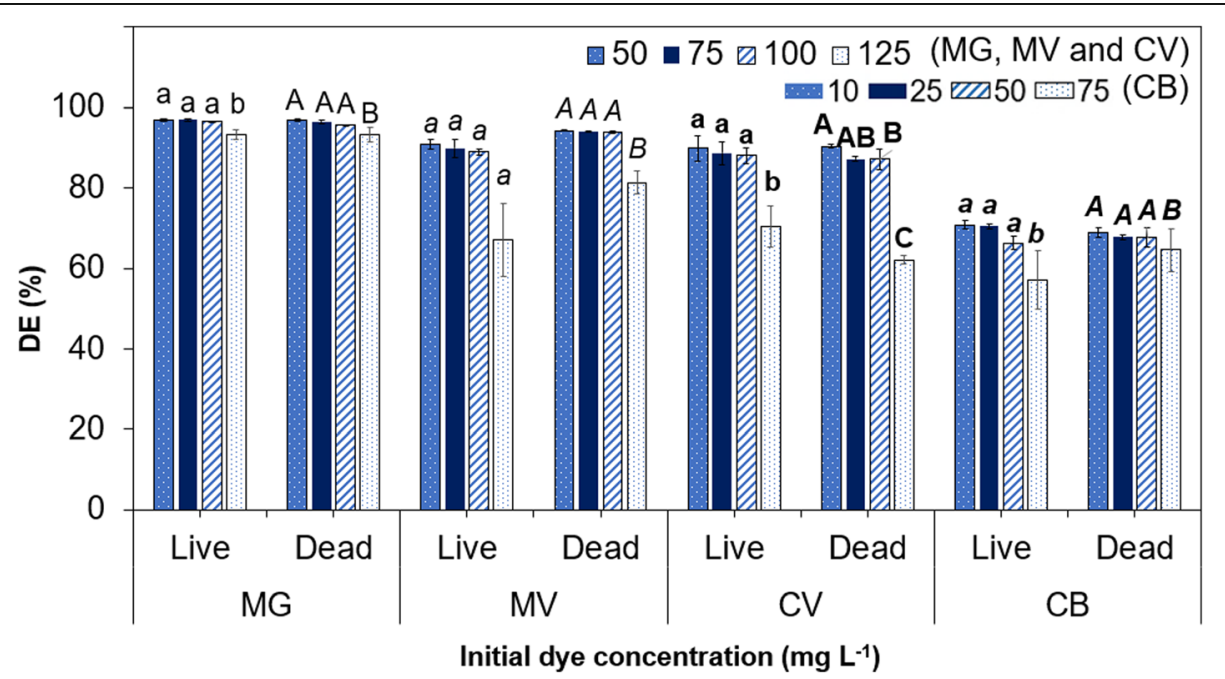

Fig. 7 Effect of initial dye concentrations on the DE of TPM dyes by Streptomyces isolate (live and dead cells). Means with the same letters (lowercase, live cells; uppercase, dead cells) and font style (MG, regular; MV, italic; CV, bold; CB, bold italic) are not significantly different at HSD (o.05). Bars indicate \pm SEM 


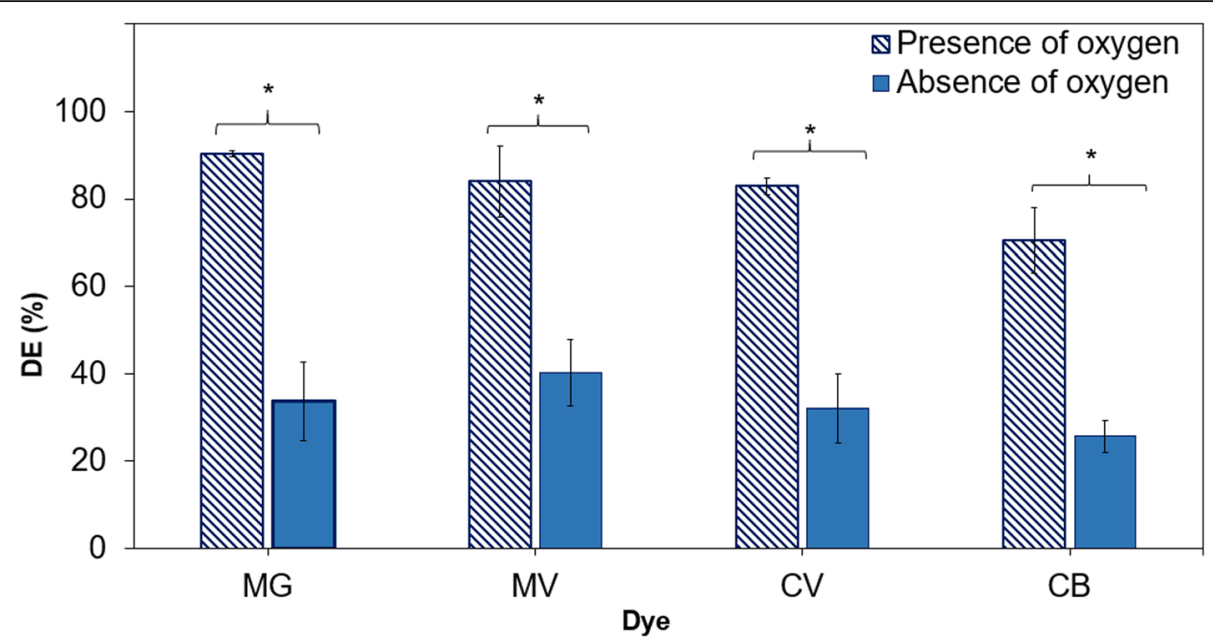

Fig. 8 Effect of oxygen on the DE of TPM dyes by Streptomyces isolate. ${ }^{\prime * \prime}$ indicates significant difference based on paired T-test $(p<0.05)$ between aerobic and anaerobic condition. Bars indicate \pm SEM

Similarly, dead cells also recorded optimum initial dye concentration at $100 \mathrm{mg} \mathrm{L}^{-1}$ (MG, MV, CV) and $50 \mathrm{mg}$ $\mathrm{L}^{-1}(\mathrm{CB})$. Dye removal efficacy for $\mathrm{MG}, \mathrm{MV}, \mathrm{CV}$, and $\mathrm{CB}$ was $96,94,87$, and $68 \%$, respectively (Fig. 7 ). When higher initial dye concentrations (i.e., $125 \mathrm{mg} \mathrm{L}^{-1}$ for $\mathrm{MG}, \mathrm{MV}, \mathrm{CV}$, and $75 \mathrm{mg} \mathrm{L}^{-1}$ for $\mathrm{CB}$ ) were used, the $\mathrm{DE}$ for dead cells was significantly lower with $93,81,62$, and $65 \%$ (Fig. 7). When higher dye concentrations were applied, saturation of dye molecules may have occurred, limiting electrostatic interaction between dye molecules and functional groups on the surface of dead cells [32]. As a result, the removal of TPM dyes decreased.
Influence of oxygen on the decolorization of TPM dyes by live cells

Results showed that live cells achieved higher DE in the presence of oxygen. The presence of oxygen enhanced the decolorization of MG (90\%), followed by $\mathrm{MV}, \mathrm{CV}$, and $\mathrm{CB}$ at 84,83 , and $71 \%$ (Fig. 8). By contrast, the decolorization activities for the same dyes in the absence of oxygen were inferior, with significantly lower DE for MG (34\%), MV (40\%), CV (32\%), and CB (26\%) (Fig. 8). Similar observations were reported by Mane et al. [16] in which S. krainskii demonstrated higher decolorization activity (95\%) on Reactive Blue-59 in the presence of

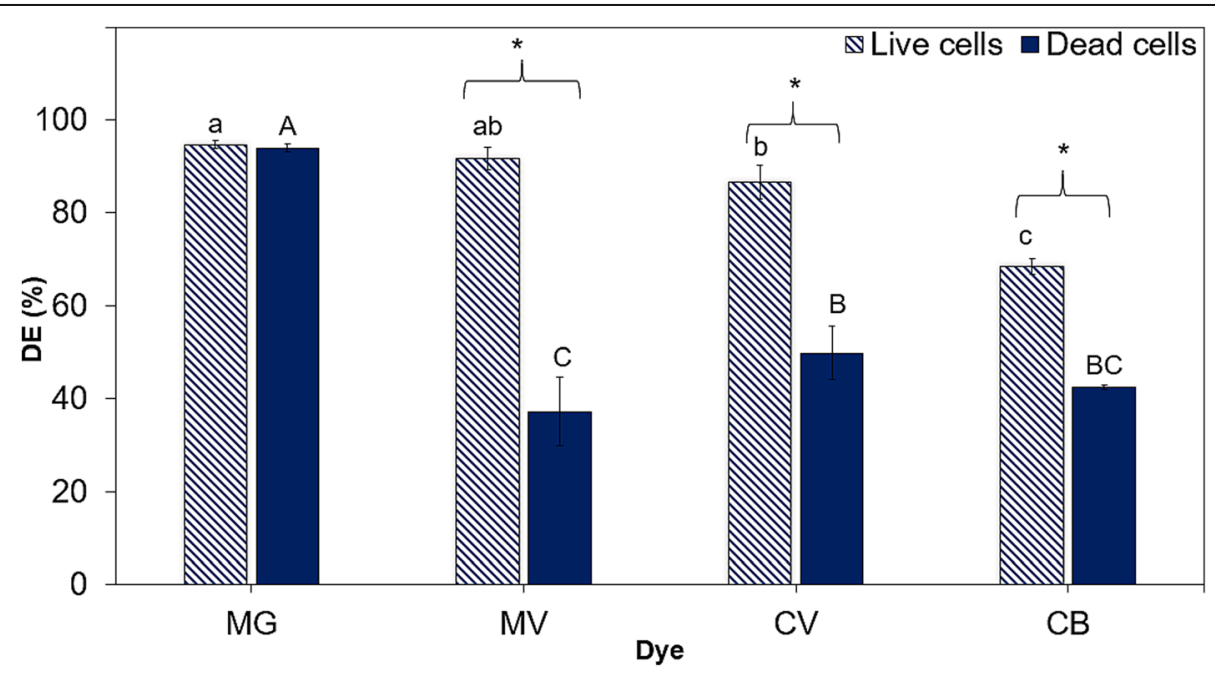

Fig. 9 Comparison of maximum DE by live and dead cells on TPM dyes at combined optimized conditions. Means with the same small letters (live cells) and the same capital letters (dead cells) are not significantly different at HSD (0.05). Bars indicate \pm SEM. ${ }^{* \prime \prime}$ indicates significant difference based on paired T-test $(p<0.05)$ between live and dead cells 
oxygen. The influence of oxygen and the enhanced decolorization efficiency by live cells is anticipated as Streptomyces are aerobic bacteria [39]. Species of Streptomyces require oxygen for their growth and the production of enzymes [39]. This includes oxidative enzymes, e.g., laccase, lignin peroxidase, and manganese peroxidase [39]. Studies [37, 40] reported oxidative enzymes are involved in the degradation of TPM dyes by breaking the double bond of the chromophore. As a consequence, efficient decolorization was achieved by this Streptomyces isolate in the presence of oxygen. On the contrary, anaerobic conditions may have caused poor survivability for Streptomyces and affected their metabolism [41]. Lower enzyme activity may have been produced [42], resulting in poor DE of TPM dyes. In short, this Streptomyces isolate decolorized the dyes better in the presence of oxygen.

\section{Removal of TPM dyes by live and dead cells using optimized conditions}

Both live and dead cells showed better removal for TPM dyes when applied for dye treatment using optimized conditions. At optimized conditions, live cells demonstrated higher decolorization for MG (95\%), MV (92\%), CV (87\%), and CB (68\%) (Fig. 9) compared to DE achieved using non-optimized conditions, i.e., 86 (MG), 13 (MV), 2 (CV), and 51\% (CB) (Fig. 3). Rapid decolorization was also observed when incubated at optimized conditions, in which 89 (MG), 88 (MV), 71 $(\mathrm{CV})$, and $65 \%(\mathrm{CB})$ were successfully removed by live cells within the first $2 \mathrm{~h}$ (Fig. 10). On the other hand, dead cells demonstrated 94 (MG), 37 (MV), 50 (CV), and $43 \%$ (CB) of DE at optimized conditions (Fig. 9). Removal of TPM dyes by dead cells at optimized conditions was substantially higher for MG and $\mathrm{CB}$, compared to only 42 and $17 \%$ of $\mathrm{DE}$ using non-optimized conditions (Fig. 3). This may be related to properties of dyes, e.g., molecular structure and type, number or position of substituents in the dye molecule, which also play a role in decolorizing TPM dyes [43].

The efficient decolorization for all TPM dyes by live cells could be due to the higher production of enzymes [24], implying the established optimal conditions were favored by this Streptomyces isolate. Higher dye removal
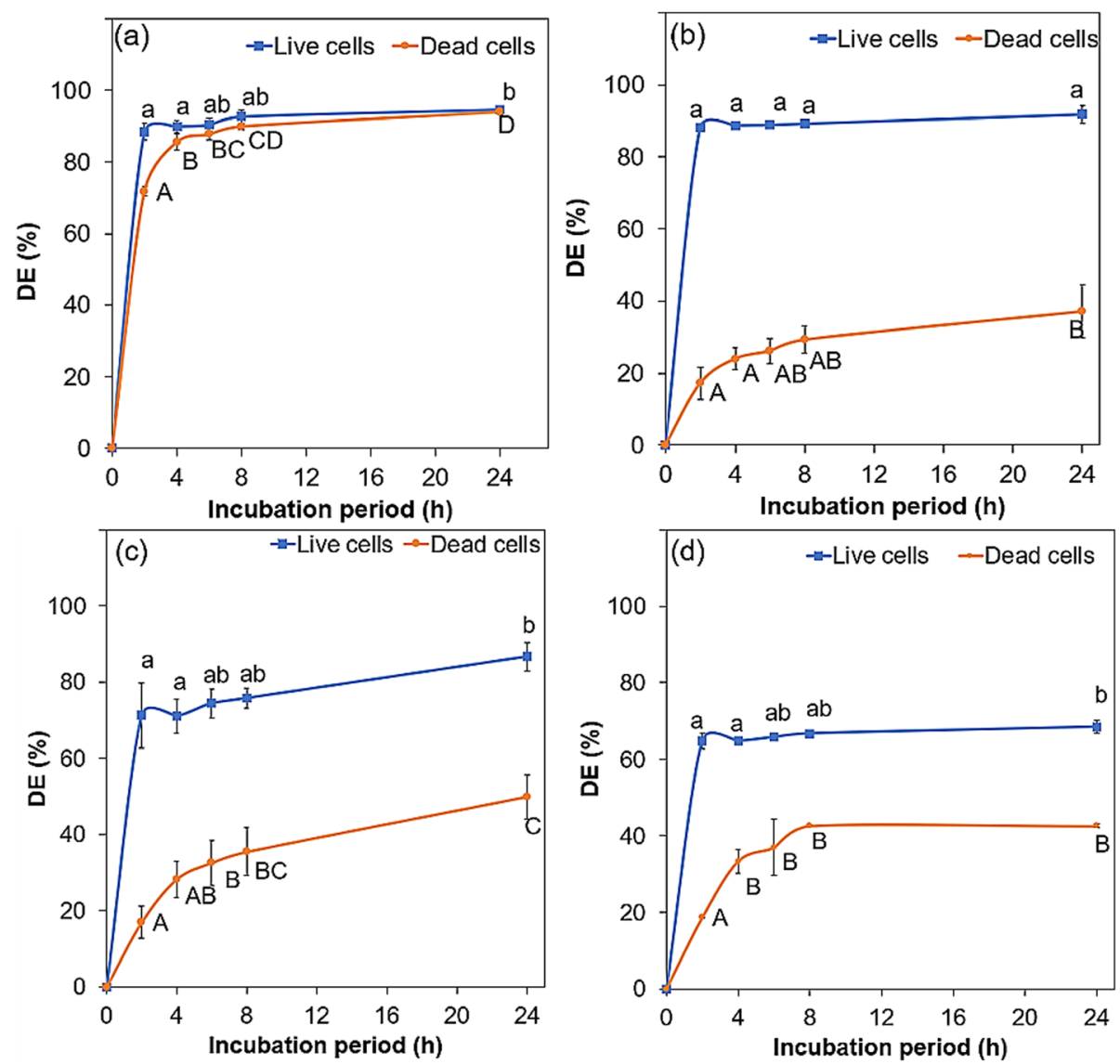

Fig. 10 Decolorization of (a) MG, (b) MV, (c) CV and (d) CB by Streptomyces isolate (live and dead cells) at combined optimized conditions throughout the incubation period. Means with the same small letters (live cells) and the same capital letters (dead cells) are not significantly different at HSD (0.05). Bars indicate \pm SEM 
Table 1 Adsorption isotherm models for the sorption of TPM dyes by live and dead cells of Streptomyces sp.

\begin{tabular}{|c|c|c|c|c|c|c|c|}
\hline \multirow[t]{2}{*}{ Cells } & \multirow[t]{2}{*}{ Dyes } & \multicolumn{3}{|c|}{ Langmuir } & \multicolumn{3}{|c|}{ Freundlich } \\
\hline & & $q_{m}$ & $\mathrm{~K}_{\mathrm{L}}$ & $\mathrm{R}^{2}$ & $n$ & $\mathrm{~K}_{\mathrm{F}}$ & $\mathrm{R}^{2}$ \\
\hline \multirow[t]{4}{*}{ Live } & MG & 12.6 & 0.011 & 0.999 & 1.64 & 1.78 & 0.986 \\
\hline & MV & 11.7 & 0.013 & 0.991 & 1.90 & 1.05 & 0.987 \\
\hline & $\mathrm{CV}$ & 9.4 & 0.038 & 0.997 & 3.04 & 2.98 & 0.972 \\
\hline & $\mathrm{CB}$ & 10.9 & 0.011 & 0.997 & 1.43 & 4.36 & 0.987 \\
\hline \multirow[t]{4}{*}{ Dead } & MG & 11.9 & 0.010 & 0.998 & 1.67 & 1.43 & 0.977 \\
\hline & MV & 11.7 & 0.013 & 0.988 & 1.81 & 1.02 & 0.987 \\
\hline & $\mathrm{CV}$ & 8.9 & 0.036 & 0.995 & 2.78 & 4.19 & 0.969 \\
\hline & $C B$ & 11.5 & 0.010 & 0.998 & 1.42 & 3.31 & 0.986 \\
\hline
\end{tabular}

using optimized conditions was also reported when live cells of Lysinibacillus fusiformis and Pseudomonas aeruginosa were investigated for the removal of azo dyes; Methyl Red [44] and Remazol Black B [45], respectively. This study concluded that the optimized conditions have resulted in a rapid and efficient decolorization of TPM dyes, primarily for live cells. The rapid decolorization of dyes by Streptomyces sp. established the potential of Streptomyces sp. for use in TPM dye removal. This contributes immensely to the existing knowledge of dye removal by Streptomyces sp., which have mostly focused on azo dyes to date [15-17]. Streptomyces sp. are now discovered to have the ability to biodegrade TPM dyes (i.e., MG, MV, CV, CB) and possibly to assimilate their biodegraded compounds, just as their utilization of azo dyes as carbon source [46]. This significant discovery further expounds the dye-degrading potential of Streptomyces sp. on various dye pollutants.

\section{Adsorption isotherm kinetics}

Langmuir isotherm is revealed to have a better fit to describe the sorption of TPM dyes, with higher $\mathrm{R}^{2}$ values for both live $\left(R^{2}=0.991-0.999\right)$ and dead cells $\left(R^{2}=\right.$ 0.988-0.998) (Table 1) (Fig. 11). The highest maximum biosorption capacities $\left(q_{m}=9.4-12.6 \mathrm{mg} \mathrm{g}^{-1}\right) \quad$ were achieved by live cells for MG, followed by MV, CB, and CV (Table 1). For the Langmuir isotherm model, the $R_{L}$ values of $0.15-0.37$ and $0.16-0.40$ for live and dead cells, respectively, were achieved, indicating a favorable characteristic of the Langmuir isotherm model for this study (Table 1). The fit to Langmuir isotherm model also infers that the biosorption of TPM dyes to live and dead cells of Streptomyces sp. was likely a monolayer sorption

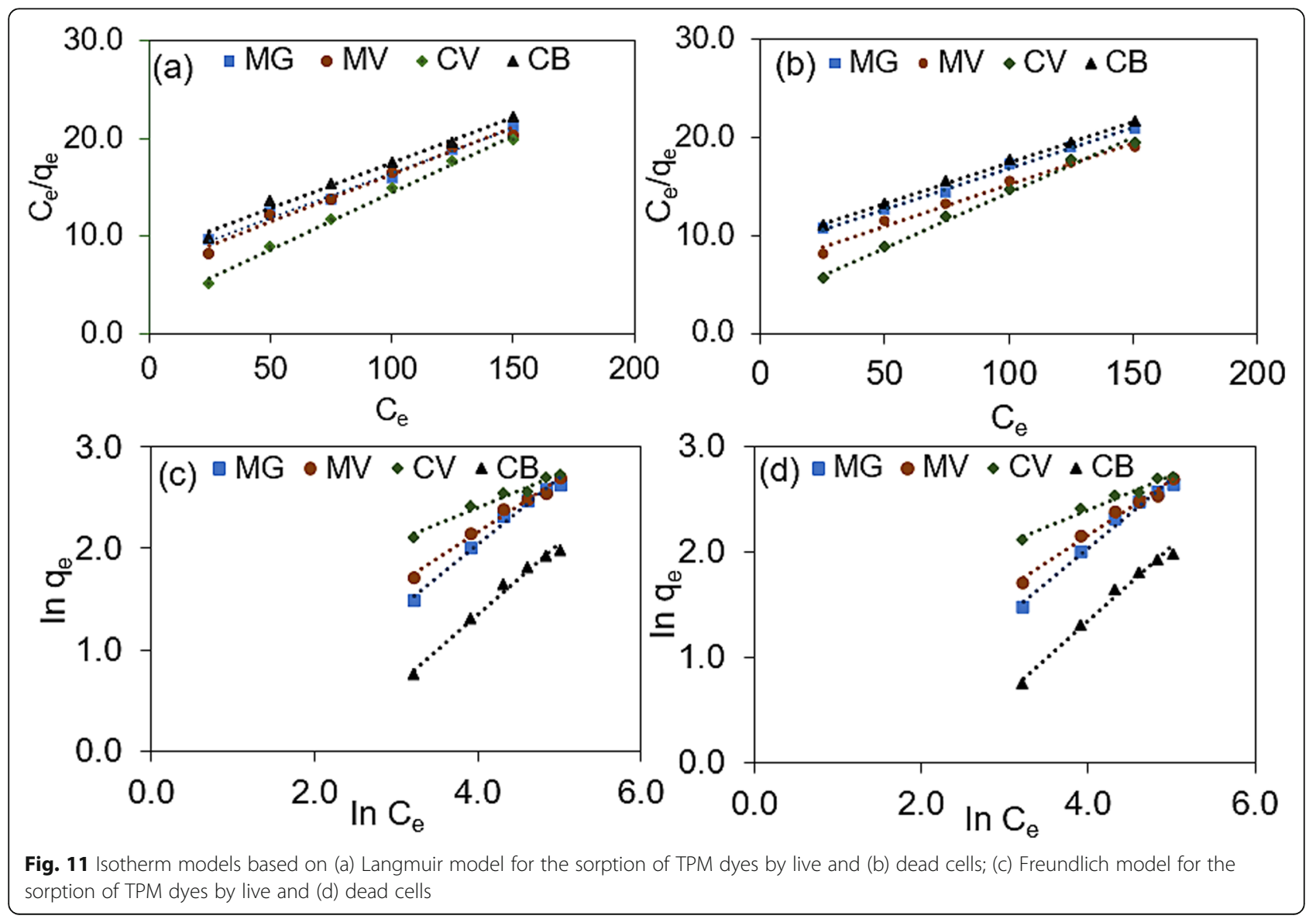




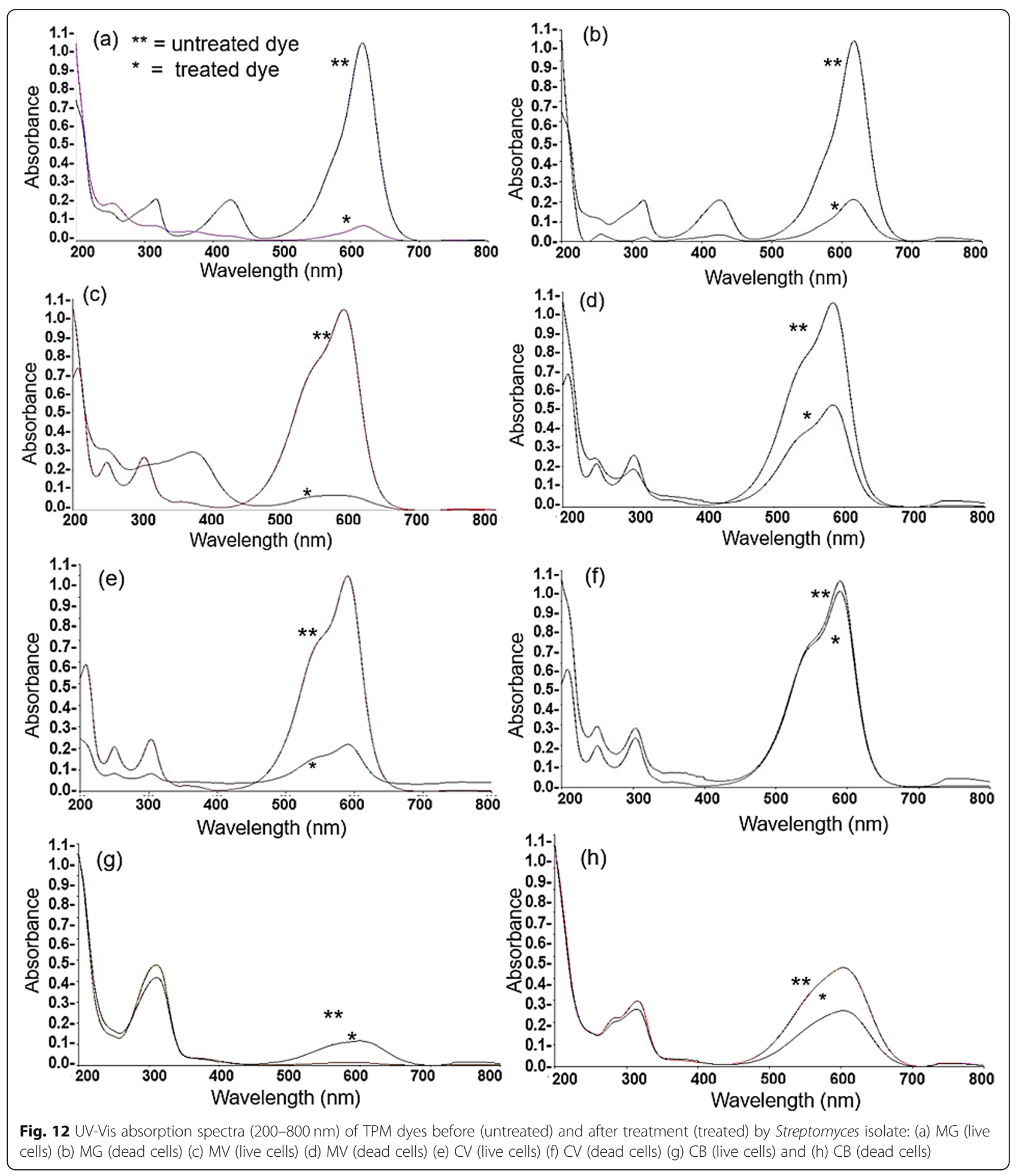

process. The surface area of live and dead cells of Streptomyces sp. is therefore critical as dye sorption becomes limited when the active binding sites on the surface are saturated with dye molecules [26].

On the contrary, the lower $\mathrm{R}^{2}$ values for the Freundlich isotherm model for both live and dead cells suggested that the sorption was not to a heterogenous surface but a monolayer sorption as evidence in the Langmuir isotherm. Nevertheless, higher $K_{F}(1.05-4.36)$ and $n(1.43-3.04)$ values obtained for live cells suggested that greater sorption capacity and interaction with the dye molecules may have been observed compared to 
dead cells $\left(K_{F}=1.02-4.19 ; n=1.42-2.78\right)$ (Table 1$)$. This suggested that live cells may have a different degree of sorption capacity compared to dead cells. Similar observations on isotherms have been reported by the fungus Haematonectria haematococca for the removal of anthraquinone dye [43]. This study has therefore suggested the benefit of using live cells for the sorption of TPM dyes.

\section{Biosorption and biodegradation potential of TPM dyes by Streptomyces sp.}

The removal of TPM dyes by live and dead cells of Streptomyces sp. at optimum conditions indicated the occurrence of biodegradation and biosorption. In this study, changes in the UV-Vis absorption spectra (200$800 \mathrm{~nm}$ ) between untreated and treated dyes with live cells were observed. The occurrence of biodegradation is marked by the absence of the dye absorption peak [2]. Spectra of untreated dye $(0 \mathrm{~h})$ revealed peaks at 617 , 584,590 , and $599 \mathrm{~nm}$, which identifies with the typical peaks of MG, MV, CV, and CB, respectively (Fig. 12). This suggested that for untreated dyes, the dye chromophores were intact and detectable, as no biosorption and biodegradation has occurred.

Upon treatment with live cells, the absorption peaks were observed to have either reduced in intensity (MG, MV, CV) or the peaks have almost disappeared (CB) (Fig. 12). This implies that a certain degree of degradation of TPM dyes has occurred due to the breakdown of the dye chromophore [22]. The association of dye biodegradation with absence of peaks is an approach used by many to describe biodegradation of dyes by Aspergillus niger [34], Penicillium simplicissimum [37], and Lysinibacillus fusiformis [44]. Although enzymes responsible for biodegradation of dyes by Streptomyces sp. were not investigated in this study, it is suggested that it may be attributed to peroxidases and laccases, capable of breaking dye molecules into smaller and less toxic compounds [47]. The toxicity of the treated dyes was not determined in this study, but can be confirmed via phytotoxicity tests using seed germination [44], including a separate study by Buntic et al. [11] on phytotoxicity of CV treated with $S$. microflavus.

For TPM dyes treated with dead cells, all absorption peaks remained visible (Fig. 12). No major changes in the absorption peaks indicated that the original structure of TPM dyes remained intact, and dye chromophores were not degraded [24]. It was however observed that the creamy-white pellets (dead cells) turned into dyecolored biomass upon introduction into dye solutions. Colored-biomass is likely the result of the sorption of TPM dyes onto the biomass surface [24]. The biosorption is said to have occurred and may have been attributed to the functional groups (e.g., hydroxyl, carboxyl, and amino) present on the surface of biomass with dye molecules, verified via Fourier transform infrared spectroscopy [32]. The dominance of either mechanism was not distinguished as both mechanisms usually occur together, except for dead cells where biosorption is the only mechanism involved.

\section{Conclusions}

This study revealed the decolorization potential of Streptomyces sp. (presumably S. bacillaris MN262194 based on 16S partial sequencing) on TPM dyes. It was established that the decolorization efficiency of the live and dead cells was influenced by $\mathrm{pH}$, agitation speed, biomass, initial dye concentration, and oxygen. The removal of TPM dyes by live and dead cells was better when optimized conditions were implemented. It was also revealed that the application of live cells was more effective than the use of dead cells, where almost complete decolorization of MG and MV was observed. The efficient decolorization activities by live cells have been attributed to the degradation of dyes. This study proposed Streptomyces sp. (S. bacillaris MN262194) as an effective dye degrader of carcinogenic TPM dyes. Future explorations may include immobilization and transfer of technology for bioremediation of other TPM dyes.

\section{Acknowledgements \\ The authors would like to thank Monash University Malaysia for the research funding and facilities.}

\section{Authors' contributions}

NHA carried out the experiments, analyzed the findings and prepared the initial draft of the manuscript. ASYT conceptualized the project and advised on methodology and data interpretation. ASYT and YYL supervised the project and were involved in the drafting and editing of the manuscript. All authors have read and approved the final draft of the manuscript prior to submission.

\section{Authors' information}

$\mathrm{NHA}$ is completing her $\mathrm{PhD}$ and will return to her lectureship position upon graduation. Her focus is on microbiology and is interested to solve issues related to environmental microbiology. YYL is a senior academic in School of Science who specializes in chemistry. ASYT is currently the Head of Discipline (Biological Science) and her interest is in Applied Microbiology. She has published many papers pertaining to the beneficial use of microbes for sustainability.

\section{Funding}

The research was funded by School of Science, Monash University Malaysia.

\section{Availability of data and materials}

The data that support the findings of this study are available from the corresponding author, upon request.

\section{Competing interests}

The authors declare that they have no conflict of interest arising from the publication of the findings.

\section{Author details}

${ }^{1}$ School of Science, Monash University Malaysia, 47500 Bandar Sunway, Selangor Darul Ehsan, Malaysia. ${ }^{2}$ School of Biology, Universiti Teknologi MARA, 72000 Kuala Pilah, Negeri Sembilan, Malaysia. 
Received: 7 November 2020 Accepted: 8 February 2021

\section{Published online: 19 February 2021}

\section{References}

1. Przystas W, Zablocka-Godlewska E, Grabinska-Sota E. Biological removal of azo and triphenylmethane dyes and toxicity of process by-products. Wate Air Soil Poll. 2012;223:1581-92.

2. Chen SH, Cheow YL, Ng SL, Ting ASY. Biodegradation of triphenylmethane dyes by non-white rot fungus Penicillium simplicissimum: enzymatic and toxicity studies. Int J Environ Res. 2019;13:273-82.

3. Singh RP, Singh PK, Singh RL. Present status of biodegradation of textile dyes. Curr Trends Biomed Eng Biosci. 2017;3:555618.

4. Abbas M, Adil M, Ehtisham-ul-Haque S, Munir B, Yameen M, Ghaffar A, et al. Vibrio fischeri bioluminescence inhibition assay for ecotoxicity assessment: a review. Sci Total Environ. 2018;626:1295-309.

5. Ramachandran P, Sundharam R, Palaniyappan J, Munusamy AP. Potential process implicated in bioremediation of textile effluents: a review. Adv Appl Sci Res. 2013:4:131-45.

6. Iqbal M. Vicia faba bioassay for environmental toxicity monitoring: a review. Chemosphere. 2016;144:785-802.

7. Oplatowska M, Donnelly RF, Majithiya RJ, Kennedy DG, Elliott CT. The potential for human exposure, direct and indirect, to the suspected carcinogenic triphenylmethane dye Brilliant Green from green paper towels. Food Chem Toxicol. 2011;49:1870-76.

8. Iqbal M, Ahmad MZ, Bhatti IA, Qureshi K, Khan A. Cytotoxicity reduction of wastewater treated by advanced oxidation process. Chem Int. 2015;1:53-9.

9. Khan NUH, Bhatti HN, labal M, Nazir A. Decolorization of basic turquise blue X-GB and basic blue X-GRRL by the Fenton's process and its kinetics. Z Phys Chem. 2019;233:361-73.

10. Ukpaka CP. BTX degradation: the concept of microbial integration. Chem Int. 2017:3:8-18

11. Buntic AV, Pavlovic MD, Antonovic DG, Siler-Marinkovic SS, DimitrijevicBrankovic SI. A treatment of wastewater containing basic dyes by the use of new strain Streptomyces microflavus CKS6. J Clean Prod. 2017;148: 347-54.

12. Remenar M, Karelova E, Harichova J, Zamocky M, Krcova K, Ferianc P. Actinobacteria occurrence and their metabolic characteristics in the nickelcontaminated soil sample. Biologia. 2014;69:1453-63.

13. Sivalingam $P$, Hong K, Pote J, Prabakar K. Extreme environment Streptomyces: potential sources for new antibacterial and anticancer drug leads? Int J Microbiol. 2019:2019:5283948.

14. Pastigrigsby MB, Paszczynski A, Goszczynski S, Crawford DL, Crawford RL. Influence of aromatic substitution patterns on azo dye degradability by Streptomyces spp. and Phanerochaete chrysosporium. Appl Environ Microb. 1992:58:3605-13.

15. Dube E, Shareck F, Hurtubise Y, Beauregard M, Daneault C. Decolourization of recalcitrant dyes with a laccase from Streptomyces coelicolor under alkaline conditions. J Ind Microbiol Biot. 2008:35:1123-9.

16. Mane UV, Gurav PN, Deshmukh AM, Govindwar SP. Degradation of textile dye reactive navy-blue Rx (Reactive blue-59) by an isolated Actinomycete Streptomyces krainskii SUK-5. Malays J Microbiol. 2008;4:1-5.

17. El-Sersy NA, Abou-Elela GM, Hassan SW, Abd-Elnaby H. Bioremediation of acid fast red dye by Streptomyces globosus under static and shake conditions. Afr J Biotechnol. 2011:10:3467-74.

18. Silva MS, Sales AN, Magalhaes-Guedes KT, Dias DR, Schwan RF. Brazilian Cerrado soil actinobacteria ecology. Biomed Res Int. 2013:2013.

19. Burghal AA, Mahdi KH, Al-Mudaffar NA. Isolation and identification of actinomycetes strains from oil refinery contaminated soil, Basrah-Iraq. Int J Innov Eng Technol. 2015;5:20-7.

20. Shirokikh IG, Solovyeva ES, Ashihmina TJ. Functional and structural features of streptomycete complexes isolated from soils with varying degrees of heavy-metal contamination. Contemp Probl Ecol. 2015;8: $125-32$.

21. Vijayabharathi $R$, Kumari BR, Sathya A, Srinivas $V$, Abhishek R, Sharma $\mathrm{HC}$, et al. Biological activity of entomopathogenic actinomycetes against lepidopteran insects (Noctuidae: Lepidoptera). Can J Plant Sci. 2014;94: 759-69.

22. Chen SH, Ting ASY. Biodecolorization and biodegradation potential of recalcitrant triphenylmethane dyes by Coriolopsis sp. isolated from compost. J Environ Manage. 2015;150:274-80.
23. Stach JEM, Maldonado LA, Ward AC, Goodfellow M, Bull AT. New primers for the class Actinobacteria: application to marine and terrestrial environments. Environ Microbiol. 2003;5:828-41.

24. Ting ASY, Lee MVJ, Chow YY, Cheong SL. Novel exploration of endophytic Diaporthe $\mathrm{sp}$. for the biosorption and biodegradation of triphenylmethane dyes. Water Air Soil Poll. 2016;227:109.

25. Preethi G, Sridhar S, Chandra JH. Optimization of process parameters influencing decolourization of Navy Blue-HER using simplex centroid mixture design. Pollut Res. 2015;34:59-64.

26. Saruchi, Thakur $P$, Kumar $V$. Kinetics and thermodynamic studies for removal of methylene blue dye by biosynthesize copper oxide nanoparticles and its antibacterial activity. J Environ Health Sci. 2019:17:367-76.

27. Shariffah-Muzaimah SA, Idris AS, Madihah AZ, Dzolkhifli O, Kamaruzzaman S, Maizatul-Suriza M. Characterization of Streptomyces spp. isolated from the rhizosphere of oil palm and evaluation of their ability to suppress basal stem rot disease in oil palm seedlings when applied as powder formulations in a glasshouse trial. World J Microb Biot. 2018;34:15.

28. Jiang JY, He XF, Cane DE. Biosynthesis of the earthy odorant geosmin by a bifunctional Streptomyces coelicolor enzyme. Nat Chem Biol. 2007:3:711-5

29. Pillai HPJS. Streptomyces consortium for enhanced biodegradation of azo blue dye. J Pure Appl Microbiol. 2018;12:65-72.

30. Kontro M, Lignell $U$, Hirvonen MR, Nevalainen A. pH effects on 10 Streptomyces spp. growth and sporulation depend on nutrients. Lett Appl Microbiol. 2005:41:32-8.

31. Semu E, Akishule D. Growth of Streptomyces isolates from four soils in Morogoro, Tanzania, under culture-media pH conditions other than their original environmental pH. Tanzan J Nat Appl Sci. 2011;2:424-32.

32. Dotto GL, Sharma SK, Pinto LAA. Biosorption of organic dyes: research opportunities and challenges. In: Sharma SK, editor. Green chemistry for dyes removal from wastewater: research trends and applications. Beverly: Scrivener; 2015. p. 295-329.

33. Sarkar K, Banerjee SL, Kundu PP. Removal of anionic dye in acid solution by self crosslinked insoluble dendronized chitosan. Hydrol Curr Res. 2012;3: 1000133.

34. Asses N, Ayed L, Hkiri N, Hamdi M. Congo red decolorization and detoxification by Aspergillus niger: removal mechanisms and dye degradation pathway. Biomed Res Int. 2018;2018:3049686.

35. Uppala R, Sundar K, Muthukumaran A. Decolorization of azo dyes using dried biomass of Bacillus cereus RC1 and Kocuria kristinae RC3. J Pure Appl Microbio. 2019;13:1969-76.

36. Doganli GA, Bozbeyoglu N, Akdogan HA, Dogan NM. Biodecolourization and biotransformation of textile dyes remazol violet-5R and remazol brillant orange-3R by Bacillus sp. DT9 isolated from textile effluents. Global Nest J. 2017:19:176-81.

37. Chen SH, Ting ASY. Biosorption and biodegradation potential of triphenylmethane dyes by newly discovered Penicillium simplicissimum isolated from indoor wastewater sample. Int Biodeter Biodegr. 2015;103:1-7.

38. Lima DR, Klein L, Dotto GL. Application of ultrasound modified corn straw as adsorbent for malachite green removal from synthetic and real effluents. Environ Sci Pollut R. 2017;24:21484-95.

39. Saini A, Aggarwal NK, Sharma A, Yadav A. Actinomycetes: a source of lignocellulolytic enzymes. Enzyme Res. 2015;2015:279381.

40. Jadhav JP, Govindwar SP. Biotransformation of malachite green by Saccharomyces cerevisiae MTCC 463. Yeast. 2006:23:315-23.

41. Sawers RG, Fischer M, Falke D. Anaerobic nitrate respiration in the aerobe Streptomyces coelicolor A3(2): helping maintain a proton gradient during dormancy. Env Microbiol Rep. 2019;11:645-50.

42. Baez A, Shiloach J. Effect of elevated oxygen concentration on bacteria yeasts, and cells propagated for production of biological compounds. Microb Cell Fact. 2014;13:181.

43. Rybczynska-Tkaczyk K, Kornillowicz-Kowalska T. Biosorption optimization and equilibrium isotherm of industrial dye compounds in novel strains of microscopic fungi. Int J Environ Sci Te. 2016;13:2837-46.

44. Sari IP, Simarani K. Decolorization of selected azo dye by Lysinibacillus fusiformis W1B6: biodegradation optimization, isotherm, and kinetic 
study biosorption mechanism. Adsorpt Sci Technol. 2019;37:492-508.

45. Hashem RA, Samir R, Essam TM, Ali AE, Amin MA. Optimization and enhancement of textile reactive Remazol black $B$ decolorization and detoxification by environmentally isolated $\mathrm{pH}$ tolerant Pseudomonas aeruginosa KY284155. AMB Express. 2018;8:83.

46. Jamee R, Siddique R. Biodegradation of synthetic dyes of textile effluent by microorganisms: an environmentally and economically sustainable approach. Eur J Microb Im. 2019;9:114-8.

47. Mishra S, Maiti A. Applicability of enzymes produced from different biotic species for biodegradation of textile dyes. Clean Technol Envir. 2019;21:763-81.

\section{Publisher's Note}

Springer Nature remains neutral with regard to jurisdictional claims in published maps and institutional affiliations.

Ready to submit your research? Choose BMC and benefit from:

- fast, convenient online submission

- thorough peer review by experienced researchers in your field

- rapid publication on acceptance

- support for research data, including large and complex data types

- gold Open Access which fosters wider collaboration and increased citations

- maximum visibility for your research: over $100 \mathrm{M}$ website views per year

At $\mathrm{BMC}$, research is always in progress.

Learn more biomedcentral.com/submissions 